\title{
Technology Incubator Performance in New Zealand
}

\author{
Nigel George Yee \\ Faculty of Technology and the Built Environment \\ Unitec New Zealand \\ Auckland, New Zealand \\ e-mail: nyee@unitec.ac.nz
}

\begin{abstract}
Business incubation and technology incubation is an area where new ideas are combined with resources and expertise in order to produce viable products and businesses. The business and technology incubation sector in New Zealand is relatively young compared to the United States and a government program administered by New Zealand Trade and Enterprise provides assistance to incubators by way of government assistance programs and targeted funding. Administration of the program requires incubators that are recipients of government funding provide information on their performance so that New Zealand Trade and Enterprise can assess the performance of the incubation programs. From this data a Return on Investment analysis is taken which provides indicators of the effectiveness of the incubation program. Due to the newness of the incubation programs in New Zealand, a limited amount of performance metrics are compiled for a comparative analysis. The paper presents performance indicators of the technology and business incubation programs supported by New Zealand Trade and Enterprise and discusses future metrics for a more detailed analysis of performance.
\end{abstract}

Keywords-Incubator, Return on Investment, Performance.

\section{INTRODUCTION}

In today's society, companies that have a focus on developing new products and innovation are companies with higher profit margins and this translates into higher salaried incomes for employees in innovative companies [1]. A nation's business sector is comprised of many business entities and the future success of a business entity depends on its ability to innovate; business entities without the ability to innovate are increasing finding themselves without a mechanism that allows them to remain competitive and grow in high wage, high profit industries [2]. In private industry, innovation is now considered to supersede quality as a means of obtaining a competitive advantage and a national innovation business strategy is considered a necessity for a nation wishing to have a first world standard of living [3].

Innovation is dependent on the creation of new knowledge and the creation of new knowledge in the modern economy is mainly achieved by the use of research thus research based innovation is considered to be a highly prized commodity in the modern economy as it is assumed that research based innovation generates new economic activity and increases the available wealth [4]. To increase the amount of innovation in a nation's economy, governments are increasing manipulating levers to encourage existing private organisations to move beyond their existing capabilities [5]. Likewise organisations are also investigating ways of manipulating the levers and processes for increased levels of innovation (see Fig.1). The technology incubator is a entity where knowledge is transformed into innovative products and services thus the manipulation of mechanisms for increase levels of innovation is investigated (within this work), in respect to the technology incubator.

Within Higher Education Academies in many developed countries, there is a substantial body of work describing constant innovation and changing approaches to knowledge management and knowledge generation with the end outcome being technology transfer into the private sector using the mechanisms of technology incubators and technology parks. In keeping with this trend New Zealand has embarked on the development of technology incubators and technology parks based on overseas models with a number of academic institutions and private companies having established technology incubators, technology incubators supported by New Zealand Trade and Enterprise (NZTE) are presented as follows -

- The University of Auckland, Icehouse Incubator.

- The Massey University Albany E-Centre.

- The Auckland University of Technology (AUT) business innovation centre.

- Palmerston North, Bio Commerce Centre.

- Wellington City, Creative HQ.

- Lincoln University, Powerhouse Ventures.

- Upstart Business Incubator - an incubator predominantly tied to Otago University but serving a number of different organisations.

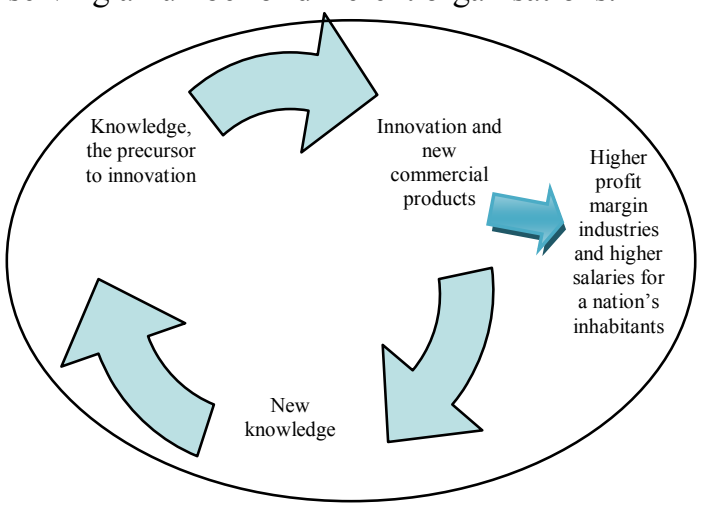

Figure 1. Rational for an innovation planning strategy. 
This paper presents current data pertaining to New Zealand technology incubators and outlines future data compilations and research effort on the performance of New Zealand technology incubators. The paper serves as the first paper in a series of papers intended to provide both a comparative performance break down of New Zealand technology incubators and insight into the working dynamics of New Zealand incubators.

\section{DEFINITION OF AN INCUBATOR}

A technology incubator is an entity that assists and encourages innovation. An earlier definition of an incubator is a defined geographical location [6], where services are offered. In this definition, the incubator is an entity consisting of a controlled physical or virtual area that assists new start up ${ }^{1}$ ventures and new businesses until they are able to be self supporting using conventional business resources. Incubator elements (situated within a localized area) are defined as on-site management and management resources, marketing, physical space, shared IT services and access to finance or start-up capital for business growth.

Another description of the incubator [7] addresses the conceptual differences between the incubator and traditional venture capital. The differences are the incubator exists in a defined geographical location and offer services in the following areas

- Providing a complete business model with for the new venture start up.

- Providing supporting function such as lawyers, consultants, HR and marketing experts.

- Providing experienced operational staff.

- Providing infrastructure (buildings and also technology).

- Providing a community and connections and access to technology to speed up product development.

- Staff recruitment and payroll facilities.

- Forums for critiquing and disseminating ideas.

The last definition of the technology incubator [8], focuses on the technology incubator and its relationship to knowledge in the production of innovation. This description of the technology incubator is a defined geographic location that serves to combine knowledge, innovation and knowledge management to produce products and viable business entities (see Fig. 2).

From these definitions of the incubators, commonalities include, the incubator is a formalized and systematic approach is taken to the development of products and services, involving specialized resources made available for assisting businesses within the incubator which exists within a defined region.

\footnotetext{
${ }^{1}$ A new venture is commonly referred to as a start up.
}

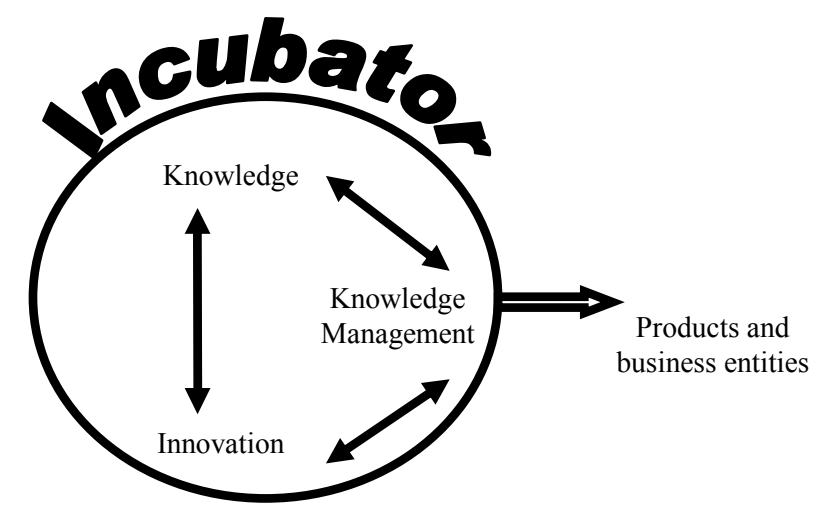

Figure 2. Knowledge transformed to produce innovations and products in an incubator.

$A$.

Types of Incubators

Incubators are primarily classified according to the type of funding used to finance the incubator; the following categories of incubators [9] are as follows-

- Real estate development initiatives - This are based on the premise that the companies that occupied the incubator stay within the real estate park and become high paying high value tenants.

- Academic - These operate in the same way as for profit incubators except the academy is the sponsoring organization that requires a return on funds they are also referred to as public for-profit incubators.

- Non-profit - These operate in the same way as the others but do not require that money is returned from the startup company within the incubator to the incubator or the donor that supplies the funding.

- For-profit - The donor or fund will have requirements such as return on investment in the start up or stock options in the corporate private for-profit incubator.

In the context of this paper the incubators funded by NZTE are now classified according to these guidelines.

TABLE I. INCUBATORS IN NEW ZEALAND CATEGORIZED ACCORDING TO TYPE.

\begin{tabular}{|l|l|}
\hline \multicolumn{1}{|c|}{ Incubator } & \multicolumn{1}{c|}{ Incubator type } \\
\hline Icehouse - University of Auckland & Academic \\
\hline E centre - Massey University & Academic \\
\hline Business Innovation Centre - AUT & Academic \\
\hline Bio Commerce Centre & Academic consortium \\
\hline Creative HQ & Academic \\
\hline Powerhouse Ventures & Academic \\
\hline Upstart business incubator & Academic \\
\hline
\end{tabular}

An interesting feature of Table $I$ is that 6 of the 7 NZTE funded incubator are academic incubators. 


\section{MeTHODOLOGY}

The methodology adopted is mainly quantitative approach, each year data is compiled by NZTE pertaining to the performance of NZTE supported incubators. The dataset compiled includes data pertaining to the operating expenses of the incubator, the amount of funding received from NZTE, the sources of funding for the incubators, the cost of incubation of each start up in the incubator, the number of exists from the incubator, the number of employees and turnover of each start up is tracked for each start up after exit.

Using the dataset for the seven current NZTE funded incubators which submitted performance data in 2008 to NZTE (Table II), the economic impact is determined by (1) below,

$$
\mathrm{E}_{\mathrm{I}}=\mathrm{T}_{\mathrm{r}}+\mathrm{T}_{\mathrm{i}}+(\text { FTEs x } \$ 80,000) \times 2
$$

where $E_{I}$ is economic impact, $T_{r}$ is total revenues, $T_{i}$ is total investment, $\$ 80,000$ is taken as the average information and communication technology industry salary and FTEs is the number of full time employees.

The $E_{I}$ value indicates the impact of incubator and the start up in terms of cash flow through both entities. The assumption is that this cash flow will have a wider impact for the community and thus provides a rational for targeted assistance. The economic impact is a useful for assessing the total value of the incubator industry.

The second indicator of incubator success is the return on investment calculation. This parameter is the ratio of the cost of incubation to the income generated from the start up during incubation and after exit from the incubator (see Table III). The parameter is monitored in regards to the effect of changes in policies within the incubator and the long term viability of targeted assistance to incubators.

\section{RESULtS}

Presented within the results section are compiled statistics relating to the economic impact and the return on investment of the NZTE funded incubator programs.

A

\section{Impact of incubators}

The total economic impact is provided as $\$ 417 \mathrm{~m}$ (ave. $\$ 60 \mathrm{~m}$ per incubator) using (1). Table 2 presented below provides the total costs associated with incubation in the NZTE incubators.

TABLE II. INCUBATION COSTS OF STARTUP INCUBATED IN NZTE SUPPORTED INCUBATORS

\begin{tabular}{|c|c|}
\hline Incubator Statistic & Amount \\
\hline $\begin{array}{l}\text { Total ventures in incubation as at } \\
\text { 31/12/08: } \\
\text { Average (per incubator): }\end{array}$ & $\begin{array}{l}123 \\
18\end{array}$ \\
\hline $\begin{array}{l}\text { Total exits in 2008: } \\
\text { Average: }\end{array}$ & $\begin{array}{l}28 \\
4\end{array}$ \\
\hline $\begin{array}{l}\text { Total successful exits in } 2008 \text { : } \\
\text { Average: }\end{array}$ & $\begin{array}{l}18 \\
2.6 \\
\end{array}$ \\
\hline $\begin{array}{l}\text { Total no. exited companies: } \\
\text { Average: }\end{array}$ & $\begin{array}{l}177 \\
25\end{array}$ \\
\hline $\begin{array}{l}\text { Exited companies still trading: } \\
\text { Average: }\end{array}$ & $\begin{array}{l}129 \text { (73\% of total exits) } \\
18\end{array}$ \\
\hline $\begin{array}{l}\text { Exits providing performance data: } \\
\text { Average: }\end{array}$ & $\begin{array}{l}92(71 \% \text { of companies still } \\
\text { trading) } \\
13\end{array}$ \\
\hline $\begin{array}{l}\text { Reporting companies exporting in } \\
\text { 2008: } \\
\text { Average: }\end{array}$ & $\begin{array}{l}53(58 \% \text { of reporting } \\
\text { companies) } \\
8\end{array}$ \\
\hline $\begin{array}{l}\text { Total revenue last financial year: } \\
\text { Average per incubator: } \\
\text { Average per company: }\end{array}$ & $\begin{array}{l}\$ 100,371,719 \\
\$ 14,338,857 \\
\$ 1.1 \mathrm{~m}\end{array}$ \\
\hline $\begin{array}{l}\text { Export revenue last financial year: } \\
\text { Average per incubator: } \\
\text { Average per exporting company: }\end{array}$ & $\begin{array}{l}\$ 44,533,482 \quad(44 \% \text { of total } \\
\text { revenues) } \\
\$ 6,361,926 \\
\$ 840,254\end{array}$ \\
\hline $\begin{array}{l}\text { Total capital raised by graduates: } \\
\text { Average per incubator: } \\
\text { Average per reporting company: }\end{array}$ & $\begin{array}{l}\$ 29,514,996 \\
\$ 4,216,428 \\
\$ 320,815\end{array}$ \\
\hline $\begin{array}{l}\text { Total FTEs in reporting companies: } \\
\text { Average per incubator: } \\
\text { Average per reporting company: }\end{array}$ & $\begin{array}{l}982 \\
140 \\
10.7\end{array}$ \\
\hline $\begin{array}{l}\text { Total capital raised by current } \\
\text { incubatees: } \\
\text { Average per incubator: } \\
\text { Average per incubatee company: }\end{array}$ & $\begin{array}{l}\$ 8,817,000 \\
\$ 1,259,571 \\
\$ 71,683\end{array}$ \\
\hline
\end{tabular}

$B$.

\section{Return on Investment}

The analysis to date of these incubators by the NZTE is based on a return on investment. Historically there have been 177 startups that have been incubated to exit point. As of 2008, the average cost of incubation for each startup was $\$ 50,000$ (see Table III). Using the data in table 1 the gives a Return On Investment (ROI) of $\$ 47: \$ 1$, or $\$ 94: \$ 1$ on the government's $50 \%$ cost contribution.

TABLE III. TABLE Type Styles

\begin{tabular}{|l|l|l|}
\hline \multicolumn{3}{|c|}{ 2008 Financial Year } \\
\hline Income: & $\begin{array}{l}\text { Average } \\
\text { (NZ\$000's) }\end{array}$ & $\mathbf{\%}$ \\
\hline Rent/Service fees & 182 & 19 \\
\hline Royalties/Equity exits & 0 & 0 \\
\hline Fundraising (e.g. brokerage) & 8 & 1 \\
\hline Commercial - other & 52 & 6 \\
\hline Interest & 16 & 2 \\
\hline Sponsors/stakeholders & 210 & 22 \\
\hline NZTE & 472 & 50 \\
\hline Total & $\mathbf{9 4 0}$ & $\mathbf{1 0 0}$ \\
\hline & & \\
\hline
\end{tabular}




\begin{tabular}{|l|l|l|}
\hline \multicolumn{3}{|c|}{ 2008 Financial Year } \\
\hline Income: & $\begin{array}{l}\text { Average } \\
\text { (NZ\$000's) }\end{array}$ & \% \\
\hline Expenditure: & 447 & 49 \\
\hline Personnel & 164 & 18 \\
\hline Premises & 89 & 10 \\
\hline Client services & 205 & 23 \\
\hline Operational costs & $\mathbf{9 0 5}$ & $\mathbf{1 0 0}$ \\
\hline Total & $\mathbf{3 5}$ & \\
\hline & & \\
\hline Surplus & 18 & \\
\hline & \$50,000 & \\
\hline $\begin{array}{l}\text { Average number of clients per } \\
\text { incubator as at 31/12/08 }\end{array}$ & 18 . & \\
\hline Cost per client (\$905k/18) \\
$\begin{array}{l}\text { Source: White, R.R. White @NZTE.govt.nz, 2009. Technology incubators[E-mail] Message to } \\
\text { N.Yee (nyee@unitec.ac.nz). Sent 7-9-2009. }\end{array}$
\end{tabular}

A broad break down of the sector that the incubates belonged to is, $65 \%$ of incubatees have come from ICT sector, $15 \%$ from Biotech, $10 \%$ from Specialised Manufacturing and $10 \%$ from Creative sector.

\section{DISCUSSION}

The current ROI of $\$ 47: \$ 1$ (or $\$ 94: \$ 1$ ) is expected to improve in years to come as business incubation is still relatively new in New Zealand and the performance has improved over the years that incubation programs have been run. Better selection of incubates, higher growth potential (more IP based ventures) improved access to early stage growth and more advanced incubation/acceleration/market penetration.

Currently much of the data pertaining to the internal operating parameters within New Zealand business incubators discussed this in paper is not publically available. Such data includes a breakdown of the numbers of administrative staff, IT staff, research staff, startup employees per incubator, a break down on the allocation of resources in the support staff within each incubator, a break down of the technical skills and track record of support staff within an incubator and lastly distribution of revenue from startups back to the incubator. Within the New Zealand framework competition for resources and competition between academic institutes inhibits information sharing. The lack of sharing of information inhibits a comparative statistical analysis of the internal operating characteristics of each institute to be undertaken. The next phase of this work is intended to attempt to obtain this information so that a comparative analysis can be undertaken. It is believed that such a comparative analysis could be a useful tool in identifying operating characteristics of incubators.

\section{REFERENCES}

[1] O. Galor, J. Zeira, "Income Distribution and Macroeconomics," The Review of Economic Studies, vol. 60, 1993, pp.35-52.

[2] G. Grossman, E. Helpman, Innovation and Growth in the Global Economy. $6^{\text {th }}$ ed. MIT Press: Boston, 1993.

[3] C. Freeman, L. Soete, The Economics of Industrial Innovation. Francis and Taylor: Holland, 1997.

[4] P. Saeed, "Innovation and economic activity: an institutional analysis of the role of clusters in industrializing economies," Journal of Economic Issues, vol. 42, 2008, pp.1005-1030.

[5] G. Tassey, Methods for Assessing the Economic Impacts of Government R\&D. Report: 03-1: U.S Department of Commerce, 2003.

[6] M. Gonzalez, R. Lucea, "The Evolution of Business Incubation," 2001 .

http://www.bii.ge/eng/studies_\&_Papers/\%5B5\%5D.evolutionincu bation.pdf

[7] O. Chinsomboon, "Incubators in the new economy," 2000. http:/ /www.chinsomboon.com/incubator

[8] P. Phan, D. S. Siegel, M. Wright, "Science parks and incubators: observations, synthesis and future research," Journal of Business Venturing, vol. 20, 2005, pp.165-182.

[9] F. Martin, "Business Incubators and Enterprise Development: Neither Tried nor Tested?," Small Business and Enterprise Development, vol. 4(1), 1997, pp.3-11. 